\title{
7 he comparative analysis of Lithuanian manorial- serf economy and hacienda economic system of 1 Latin America in the context of capitalist world system: from the second half of the 18th to the second half of the 19th centuries
}

\section{Darius Žiemelis}

Vilnius University, Faculty of History, Lithuania, E-mail: dariusziemelis@inbox.lt

\begin{abstract}
Rezumat

The paper compares for the first time in historiography the Lithuanian manorial-serf economy and Latin American hacienda economic systems of the second half of the 18th century to the second half of the 19th century in the context of the capitalist world system (CWS). The main focus will be on the explication in macro level of similarities and differences of structures and development trends of these systems. The analyzed period corresponds to the stage of both the dominance and intensification of manorial-serf economy in Lithuania and predominance and intensification of hacienda economy in Latin American countries and it was determined by the same factor of the industrial revolution. The study confirms the thesis that these economic systems belonged to typologically closed economic kind (they were focused on the serfdom method of production) in the global division of labor. It shows that both Lithuanian manorial-serf economy and haciendas of Latin America were not typical feudal enterprises, but displayed only peripheral (agrarian) capitalism features.

Lucrarea compară, pentru prima oară $\hat{\imath}$ istoriografie, economia lituaniană de tipul domenial-iobăgesc $\mathrm{cu}$ sistemele economice latino-americane de tip hacienda din a doua jumătate a secolului al XVIII-lea până în a doua jumătate a secolului al XIX-lea, în contextul sistemului mondial capitalist. Se va pune accentul pe explicarea la nivel macro a similitudinilor și diferențelor dintre structurile și tendințele de dezvoltare ale acestor sisteme. Perioada analizată corespunde atât stadiului dominării și intensificării economiei de tipul domenial-iobăgesc din Lituania, cât și a predominării și intensificării economiei hacienda in țările latino-americane, și a fost determinată de același factor al revoluției industriale. Studiul confirmă teza că aceste sisteme economice au aparținut tipologic economiei închise (caracterizată printr-o concentrare asupra iobăgiei ca metodă de producție) în cadrul diviziunii globale a muncii. Aceasta arată că atât economia de tipul domenial-iobăgesc lituaniană, cât și sistemul hacienda din America Latină nu erau întreprinderi feudale tipice și posedau doar unele caracteristici ale capitalismului periferic (agrar).
\end{abstract}

Keywords: Lithuanian manorial-serf economy, Latin American hacienda economy, second serfdom, second slavery, peripheral capitalism, capitalist world system concept

CC BY-SA License (https://creativecommons.org/licenses/by-sa/2.0) 


\section{Introduction}

Twenty-eight years of independence highlighted the trends and directions of research in Lithuanian history science. Structurally Lithuanian historiography became part of European historiography. On the other hand, thematically the Lithuanian science of history (as well as other humanitarian and social sciences), is still Lithuanian-centric in nature. This nature exists not only because of juvenility of those sciences. Since the beginning of the institutionalization and professionalization of these sciences in the interwar period (1918-1940) of independent Lithuania, their open (and latent during the Soviet period) mission was to testify to the world that Lithuania is not only a geographical but also a socio-cultural category. The successful completion of this mission and the integration of Lithuania into the community of European states and peoples, according to the most famous Lithuanian sociologist Zenonas Norkus, allows for Lithuanian humanities and social sciences to update their agenda and look for new ways to explore Lithuania ${ }^{1}$. Today the signs of renewal are already visible in Lithuanian science of history. Gradually, we can see historical research emerging, which examines the Lithuanian history from the regional ${ }^{2}$, world history ${ }^{3}$ and civilization ${ }^{4}$ perspectives. In addition to the national historiography we can

1 For more information, see Zenonas Norkus, Kokia demokratija, koks kapitalizmas?: Pokomunistine transformacija Lietuvoje lyginamosios istorinès sociologijos požiūriu [Which Democracy, Which Capitalism?: Post-Communist Transformation in Lithuania from the Viewpoint of Comparative Historical Sociology] (Vilnius: Vilniaus universiteto leidykla, 2008), 13, 52.

2 See primarily Edvardas Gudavičius, Lietuvos istorija, t. 1: Nuo seniausiu laiku iki 1569 metu metu [Lithuania's History, Vol. 1: From the Oldest Times to 1569] (Vilnius: Lietuvos rašytoju sąjungos leidykla, 1999).

${ }^{3}$ See Darius Žiemelis, Abieju Tautu Respublikos socialine ekonomine raida XVI-XVIII amžiuje: feodalizmas ar periferinis kapitalizmas? Istoriografine analize [Social Economic Development of the Republic of the Two Nations in the 16th-18th Centuries: Feudalism or Peripheral Capitalism? An Historiographic Analysis]. Daktaro disertacija (Unpubl. PhD diss.), humanitariniai mokslai, istorija (05 H) (Vilniaus universitetas, 2009). See also D. Žiemelis, Feudalism or Peripheral Capitalism?: Socio-Economic History of the Polish-Lithuanian Commonwealth in the 16th-18th Centuries (Saarbrücken: Lap Lambert Academic Publishing GmbH \& Co. KG 2011).

${ }^{4}$ See primarily Alfredas Bumblauskas, Wielkie Księstwo Litewskie: wspólna historia, podzielona pamięć (Warszawa: Muzeum Historii Polski, 2013); Bumblauskas, Senosios Lietuvos istorija 1009-1795 [A History of Old Lithuania 1009-1795] (Vilnius: R. Paknio leidykla, 2005). 
see the emerging general historical research ${ }^{5}$, - which has long been a common practice in European historiography ${ }^{6}$. However, according to international practice, the greatest potential renewal lies within comparative historical studies ${ }^{7}$. The main advantage of comparative perspective is the widening of historical thinking horizon with the help of regional and subcontinental perspective. This allows new interpretation of our region's past in the global (meta) civilization history context and more adequate revelation and evaluation of the investigative phenomenon ${ }^{8}$. We can see that comparative historical research in Lithuania is in its early stage ${ }^{9}$. Z. Norkus

${ }^{5}$ See Nerijus Babinskas, Moldova XIV a. viduryje - XVI a. viduryje kaip socialinès struktūros tipologijos problema [Moldova in the Middle of 14th - Middle of 16th Centuries as A Problem of Typology of Social Structure]. Daktaro disertacija (Unpubl. PhD diss.), humanitariniai mokslai, istorija (05 H) (Vilniaus universitetas, 2010).

${ }^{6}$ In Poland these studies are best represented by K. Brzechczyn in his research of evolution of Mexican society. See Krzysztof Brzechczyn, O wielości linii rozwojowych w procesie historycznym. Próba interpretacji ewolucji społeczeństwa meksykańskiego (Poznań: Wydawnictwo Naukowe UAM, 2004).

${ }^{7}$ For more information about examples, which have become classics of this type of research, see Theda Skocpol, States and Social Revolutions: A Comparative Analysis of France, Russia, and China (Cambridge: Cambridge University Press, 1979); Peter Kolchin, Unfree Labor: American Slavery and Russian Serfdom (Cambridge - MA: Belknap Press of Harvard University Press, 1987); Adam Przeworski, Democracy and the Market: Political and Economic Reforms in Eastern Europe and Latin America (Cambridge: Cambridge University Press, 1991); Bernard S. Silberman, Cages of Reason: The Rise of the Rational State in France, Japan, the United States, and Great Britain (Chicago: University of Chicago Press, 1993); Shearer D. Bowman, Masters and Lords: Mid-19th-Century U.S. Planters and Prussian Junkers (New York: Oxford University Press, 1993); Richard Biernacki, The Fabrication of Labor: Germany and Britain 16401914 (Berkeley: University of California Press, 1995); Anthony W. Marx, Making Race and Nation: A Comparison of South Africa, the United States, and Brazil (Cambridge: Cambridge University Press, 1998); Kenneth Pomeranz, The Great Divergence: China, Europe, and the Making of the Modern World Economy (Princeton: Princeton University Press, 2000).

${ }^{8}$ This result is achieved by using either an asymmetric (focus is directed on one case, whereas the material of other cases is used for descriptive causal hypotheses to justify the main case) or symmetrical (attention is evenly distributed among all the investigated cases) comparative forms. For more information on these comparison forms, see Jürgen Kocka, 'Asymmetrical Historical Comparison: The Case of the German Sonderweg', History and Theory 38, 1 (1999): 40-50; Kocka, 'Comparison and Beyond', History and Theory 42, 1 (2003): 39-44.

${ }^{9}$ See primarily Arvydas Anušauskas, 'Ginkluotos kovos dèl Baltijos šalių ir Vakarų Ukrainos nepriklausomybès lyginamoji analizė [Comparative Analysis of Armed Resistance for Independence in the Baltic Countries and Ukraine]', Genocidas ir rezistencija 2 (1997): 14-18; Saulius Pivoras, Lietuviu ir latviu pilietinés savimonés raida: XVIII a. pabaiga - XIX a. pirmoji pusé (lyginamasis aspektas) (Vilnius: Vytauto Didžiojo universiteto leidykla, 2000); 
is regarded as a classic in the emerging Lithuanian comparative historical sociology ${ }^{10}$.

This article, which belongs to the comparative historical economic sociology research direction ${ }^{11}$, is to be regarded as contributing to the

Kastytis Antanaitis, Sovietiné Lietuvos, Latvijos ir Estijos nomenklatūra (1953-1990 m.): dessningumai ir ypatumai. Daktaro disertacija (Unpubl. PhD diss.), humanitariniai mokslai, istorija (05 H) (Vytauto Didžiojo Universitetas, 2001); Zenonas Butkus, 'Valstybiniai perversmai Baltijos šalyse (1926 ir 1934 m.): panašumai ir skirtumai [Coup (d'etat) in the Baltic States (1926, 1934): Similarities and Differences]', Lietuvos istorijos studijos 18 (2006): 69-81.

10 See primarily Zenonas Norkus, An Unproclaimed Empire: The Grand Duchy of Lithuania: from the Viewopoint of Comparative Historical Sociology of Empires / translation from Lithuanian by Albina Strunga. London and New York: Routledge, Taylor \& Francis Group, 2018; Norkus,'Two Hundred Years of the Theory of Historiography in Lithuania, or How Joachim Lelewel Did Become the Pioneer of Modern Comparative History', Sociologoja. Mintis ir veiksmas 1, 36 (2015): 5-31; Н. Зенонас. Непроголошена імперія: Велике князівство Аитовське з погляду порівняльно-історичної соціологї імперій (Київ: Критика, 2016); Norkus, Du nepriklausomybès dvidešimtmečiai: Kapitalizmas, klasès ir demokratija Pirmojoje ir Antrojoje Lietuvos Respublikoje lyginamosios istorinés sociologijos požiūriu [Two Twenty-Year Periods of Independence: Capitalism, Class and Democracy in the First and Second Republics of Lithuania from the Viewpoint of Comparative Historical Sociology] (Vilnius: Aukso žuvys, 2014); Norkus, On Baltic Slovenia and Adriatic Lithuania. A Qualitative Comparative Analysis of Patterns in Post-communist Transformation (Vilnius: Apostrofa / CEU Press, 2012); Norkus, 'Imperium litewskie w międzyjednostkowych społecznościach i systemach politycznych: studium przypadku', Politeja 2 (2011): 129-154; Norkus, Kokia demokratija, koks kapitalizmas? Pokomunistinè transformacija Lietuvoje lyginamosios istorinès sociologijos požiūriu [Which Democracy, Which Capitalism?: Post-Communist Transformation in Lithuania from the Viewpoint of Comparative Historical Sociology]; Norkus, 'The Grand Duchy of Lithuania in the Retrospective of Comparative Historical Sociology of Empires', World Political Science Review 3, 4 (2007): 1-41.

${ }_{11}$ Research of comparative historical economic sociology in Lithuania is represented by: Zenonas Norkus, 'Two Periods of the Peripheric Capitalist Development: Pre-Communist and Post-Communist Eastern Europe in Comparison', Polish Sociological Review 2, 19 (2015): 131-151; Norkus, 'Catching Up And Falling Behind: Four Puzzles After Two Decades Of Post-Communist Transformation', Comparative Economic Research 18, 4 (2015): 63-79; Norkus, 'A Comparison of the Economic Growth of the Baltic States between the Two World Wars', World Political Science 12, 1 (2016): 1-23; Norkus, 'Agrarinių reformų Pirmojoje ir Antrojoje Lietuvos respublikose lyginamoji istorinè sociologinè analizė [A Comparative Historical Sociological Analysis of Agrarian Reforms in the First and the Second Republic of Lithuania]', Sociologija. Mintis ir veiksmas 1, 30 (2012): 5-52; Nerijus Babinskas, 'Economic Challenges of the Early Modern Ages and Different Responses of European Margins: Comparative Considertions on the Basis of Historiography (The Cases of Polish-Lithuanian Commonwealth and Moldavian Principality)', Revista Română de Studii Baltice și Nordice / The Romanian Journal for Baltic and Nordic Studies 4, 2 (2012): 51-62; Darius Žiemelis, 'Tipologiškai artimi Lietuvai ùkiai: Čekija, Lenkija, Vengrija ankstyvaisiais Naujaisiais laikais [Economies 
"comparative turn" which began in Lithuanian history science. The article is based on the assumption that comparison of Lithuania with typologically similar and contrasting countries allows to identify and assess more adequately economic developments in Lithuania in the context of world history. The starting point of this research is considered to be the neo-Marxist capitalist world system (CWS) concept of Immanuel Wallerstein's ${ }^{12}$ who is the most famous and influential representative of comparative historical sociology in the United States of America. According to it Lithuanian and Polish manorial serf economies of the 16th-18th centuries (focused on exporting agricultural products to the core CWS countries) are classified as similar peripheral capitalist companies with haciendas in Mexico and Brazil and slavery cotton plantations in the US Southern states in the 18th-19th centuries $^{13}$. The comparison of manorial serf economy of Lithuania and hacienda economy of Latin American countries from the second half of the 18th century to the second half of the 19th century was chosen as the topic of this article. Reasonably, there are likely to occur questions why precisely hacienda (and not plantation) economic system is the choice of comparison with Lithuania and why the period of the second half of the 18th century to the second half of the 19th century is analyzed? Both manorial serf economy of Lithuania and hacienda economy of Latin American countries system were orientated toward serfdom production method. Hacienda, which was based mainly on individual economic land socage is considered in the light of the "western" serfdom economic reception in Latin America. Therefore, economic systems which existed in different continents are considered to be

\footnotetext{
Typologically Akin to Lithuania: the Czech Republic, Poland and Hungary in the Early Modern Period]', Lietuvos istorijos metraštis 2, 2013 (2014): 87-116.

${ }^{12}$ For more information about the CWS concept, see Stephen K. Sanderson, 'World-Systems Analysis after Thirty Years: Should it Rest in Peace?', International Journal of Comparative Sociology 46, 3 (2005): 179-213; Daniel Chirot and Thomas D. Hall, 'World-System Theory', Annual Review of Sociology 8 (1982): 81-106; Darius Žiemelis, 'Immanuelio Wallersteino kapitalistinès pasaulio sistemos teorija [Immanuel Wallerstein's Theory of the Capitalist World-System]', Lietuvos istorijos studijos 16 (2005): 65-81; Krzysztof Brzechczyn, Odrębność historyczna Europy Środkowej. Studium metodologiczne (Poznań: Humaniora, 1998), 16-19.

${ }^{13}$ See more Immanuel Wallerstein, The Modern World-System I: Capitalist Agriculture and the Origins of the European World-Economy in the Sixteenth Century (New York: Academic Press, 1974), 67-129.
} 
typologically alike. The period of the second half of the 18th century to the second half of the 19th century was chosen for the research because it corresponds to both the dominance and intensification of manorial serf economy in Lithuania and of hacienda economy in Latin American countries. In Lithuania this period is identified as the second serfdom ${ }^{14}$, and in Latin America - as second slavery ${ }^{15}$, which affected hacienda economic development. The most recent historiography (Dale Tomich, Michael Zeuske) considers the second serfdom in the territories east of the Elbe River as the equivalent of the second slavery ${ }^{16}$. In my previous research on the problem of the application of the second serfdom term in the history of the Central Eastern Europe ${ }^{17}$, I reached a conclusion which corrects I. Wallerstein's CWS concept stating that the features of second serfdom (which should be considered as peripheral capitalism) are most distinctly

14 The term second serfdom was first used by F. Engels at the end of the 19th century, while describing agrarian relations based on corvée farmstead economy, which formed and established itself at the end of the 15th century - 17th century, in the territories east of the Elbe River. See 'Letter from F. Engels to K. Marx dated December 15, 16 and 22, 1882', in Karl Marx und Friedrich Engels, Briefwechsel 4. Bd.: 1868-1883 (Berlin: Dietz Verlag, 1950), 691, 693 and 698.

${ }^{15}$ For the first time the term second slavery (describing the formation of new high productivity slavery production zone in the US Southern States, Cuba and Brazil) was introduced into scientific circulation by American historian sociologist D. Tomich. Perhaps the main reason of emergence of slavery plantation economy in these areas was demand in cotton, sugar and coffee in the global market, caused by the industrial revolution. See more Dale Tomich, Through the Prism of Slavery: Labor, Capital, and World Economy (Lanham - MD: Rowman and Littlefield, 2004), 56-71

16 The assumption of it was intensification of forced labor in the production of these developing countries, similar emergence causes (e.g., agricultural production demand in (especially foreign) market). See more Dale Tomich and Michael Zeuske, 'Introduction, The Second Slavery: Mass Slavery, World-Economy, and Comparative Microhistories', Review (Fernand Braudel Center) 31, 2 (2008): 91-100.

${ }^{17}$ See, for example, Arcadius Kahan, 'Notes on Serfdom in Western and Eastern Europe', Journal of Economic History 33, 1 (1973): 86-99. For more information about the entrenchment of the term serfdom second in traditional Marxist historiography when explaining social economic development of European territories east of the Elbe River in the 16th-18th centuries, seе И. И. Костющко, 'К. Маркс и Ф. Энгельс об аграрном развитии Восточной Европы', in Ежегодник по аграрной истории Восточной Европь 1970 2. (Рига, 1977): 5-13; Darius Žiemelis, 'Lietuva Vidurio ir Rytų Europoje XVI-XVIII amžiuje: „feodalinė reakcija“ ar periferinis kapitalizmas? [Lithuania in the Central and Eastern Europe of the 16th-18th Centuries: „Feudal Reaction“ or Peripheral Capitalism?]', Lietuvos istorijos studijos 18 (2006): 55-60. 
visible in Lithuania not in the 16th-18th centuries, but in the second half the 18th century - 1861, i.e. during the second stage of economic development of manorial serf economy ${ }^{18}$. The comparative analysis of European manor and Latin American hacienda systems was carried out by Cristobal Kay. However, the author explains the structure of the European manor with examples of England and East Germany, and the structure of Latin American hacienda - with the example of Chile ${ }^{19}$. This shows that so far there has not been any comparative research concerning structures and trends of the Lithuanian manorial serf economy and Latin America hacienda economy from the second half of the 18th century to the second half of the 19th century. Therefore, the goal of this article is to present the experiment of comparative analysis of Lithuanian manorial serf economy and Latin American hacienda economy systems of second half of the 18th century to second half of the 19th century in the context of CWS. The article starts with the analysis of Lithuania's economic development in the second half of the 18th century to the second half of the 19th century in terms of peripheral capitalism concept (Part I). After highlighting the features of peripheral capitalism which are considered to be manifestations of the second serfdom and can be seen in structure and development of Lithuanian economy - the second part of the article deals with the explication of major similarities and differences between economic structures and trends in the Lithuania manorial serf economy and Latin American hacienda. The article ends with conclusions.

\footnotetext{
${ }^{18}$ See Darius Žiemelis, 'The Problem of the Application of the Term Second Serfdom in the History of Central Eastern Europe: The Case of Lithuanian Economy in the 16th-19th Centuries (until 1861)', Revista Română de Studii Baltice și Nordice / The Romanian Journal for Baltic and Nordic Studies 7, 1 (2015): 123-149.

${ }^{19}$ See Cristóbal Kay, 'Comparative Development of the European Manorial System and the Latin American Hacienda System', Journal of Peasant Studies 2, 1 (1974): 69-98.
} 


\section{Structure and Evolution of Lithuanian Economy in the} Second Half of the 18th Century to Second Half of the 19th Century in Terms of Peripheral Capitalism Concept

The first volume of I. Wallerstein's main treatise entitled the Modern world system ${ }^{20}$, which deals with the emergence of CWS in the 16th century and its early development treats the socio-economic system in Poland and Lithuania (as in America) in the 16th to the 18th centuries as the periphery of the CWS at that time. In CWS conception of the second serfdom phenomenon (serfdom dominance, emergence of large manorial serfeconomies whose production purpose was the cultivation of grain and their export, weak development of cities) from the 16th century until the 18th century is regarded as a manifestation of peripheral capitalism in Central Eastern Europe (including Lithuania) ${ }^{21}$.

Let us start the analysis from the problematic issue - can we qualify Lithuanian manorial serf economies in the 16th-18th centuries as "grain factories" or "agricultural production enterprises", producing for the (especially foreign) market? This answer is complicated by the claim supported by research that in the view of CWS (especially until the second half of the 19th century) the importance of international exchange and global market processes on the country's internal social and economic development is too exaggerated ${ }^{22}$. According to CWS theory, the main feature of peripheral capitalism is the country's economic dependence on the international market ${ }^{23}$. Research also shows weak economic involvement of

\footnotetext{
${ }^{20} \mathrm{I}$. Wallerstein's work "The Modern World-System" is considered to be a story about the history of the development of the CWS, but it is not finished, the four volumes covering the 16th-first half of 20th c. have been published. See Wallerstein, The Modern World-System I; Wallerstein, The Modern World-System II: Mercantilism and the Consolidation of the European World-Economy 1600-1750 (New York: Academic Press, 1980); Wallerstein, The Modern WorldSystem III: The Second Great Expansion of the Capitalist World-Economy (New York: Academic Press, 1989); Wallerstein, The Modern World-System IV: Centrist Liberalism Triumphant, 17891914 (Berkeley: University of California Press, 2011).

${ }^{21}$ See more Wallerstein, The Modern World-System I, 67-129.

${ }^{22}$ See, for example, Patrick O'Brien, 'European Economic Development: The Contribution of the Periphery', Economic History Review 35, 1 (1982): 1-18; Henk Wesseling, 'Overseas History', in: Burke, P. (ed.) New Perspectives on Historical Writing (Cambridge: Polity Press, 1992): 67-92.

${ }^{23}$ The distinctive feature of peripheral capitalism according to the CWS theory is the use of
} 
Lithuania in international trade from the 16th to the 18th centuries ${ }^{24}$. Here arises the second problem - the dispute of the reasons which caused the emergence of the second serfdom in Central Eastern Europe. Traditional Marxist perspective puts more emphasis on internal ${ }^{25}$, whereas CWS concept implies external causes (involvement in the hierarchical world division of labor in the terms of peripheral status). This controversy causes ${ }^{26}$ the problem of applying the term second serfdom in describing the Lithuanian social economic order in the 16th to the 18th centuries. Research shows that

forced labor (slaves, serfs). Weak statehood from a political and military point of view or colonial and semi-colonial dependence can be characteristic of the periphery's political organization. The periphery's capitalist class consists of slave-owners and landlords, whose plantations and farmsteads are capitalist enterprises producing products for sale as well as export. In the global division of labor the role of supplying the core zone states with mining and agricultural production falls to peripheral capitalism. See. Wallerstein, The Modern WorldSystem I, 349.

${ }^{24}$ See Karl von Loewe, 'Commerce and Agriculture in Lithuania, 1400-1600', Economic History Review 26, 1 (1973): 23-37; Darius Žiemelis, 'The Structure and Scope of the Foreign Trade of the Polish-Lithuanian Commonwealth in the $16^{\text {th }}$ to $18^{\text {th }}$ Centuries: The Case of the Grand Duchy of Lithuania', Lithuanian History Studies 17 (2013): 91-123.

${ }_{25}$ The internal social economic causes of emergence of second serfdom in Central Eastern Europe, are emphasized by traditional Marxist historiography. This is primarily a difference in social balance of power in favor of the nobility, weak cities, shortage of labor force, large areas of uncultivated land. In this historiographical perspective, the second serfdom concept is used to name re-feodalization process in Central Eastern Europe. Read more about the concept of genesis of second serfdom in traditional Marxist and non Marxist historiography, see Benedykt Zientara, 'Z zagadanień tzw. „wtórnego poddaństwa“ w Europie Środkowej', Prezgląd Historyczny 47, 1 (1956): 3-47; Laszlo Makkai, 'Neo-Serdom: Its Origin and Nature in East Central Europe', Slavic Review. American Quarterly of Soviet and East European Studies 34, 2 (1975): 225-238; Jerzy Topolski, 'Continuity and Discontinuity in the Development of the Feodal System in Eastern Europe (Xth to XVIIth Centuries)', Journal of European Economic History 10, 2 (1981): 373-400; Topolski, 'The Manorial Serf-Economy in Central and Eastern Europe in the Sixteenth and Seventeenth Centuries', Agricultural History 48, 3 (1974): 341-352; Doreen Warriner, 'Some Controversial Issues in the History of Agrarian Europe', Slavonic and East European Review 32, 78 (1953): 168-186; Darius Žiemelis, ‘Lietuva Vidurio ir Rytu Europoje XVI-XVIII amžiuje: „feodalinè reakcija“ ar periferinis kapitalizmas? [Lithuania in the Central and Eastern Europe of the 16th-18th Centuries: „Feudal Reaction“ or Peripheral Capitalism?]', Lietuvos istorijos studijos 18 (2006): 55-60.

${ }^{26}$ For more information about controversy of internal and external causes concerning the backwardness of Central and Central Eastern Europe from the Western Europe in the 16th18th centuries, see Brzechczyn, Odrębność historyczna Europy Środkowej, 16-19; T. H. Aston and C. H. E. Philpin (eds), The Brenner Debate: Agrarian Class Structure and Economic Development in Pre-Industrial Europe (Cambridge: Cambridge University Press, 1985). 
the term second serfdom should not be used to describe the agrarian relationships in Lithuania, in the 16th to the 18th centuries. The supporters of this approach (J. Jurginis, W. Hejnosz, Z. Janel, A. Kahan, J. Nichtweiss, J. Topolski, J. Kiaupienè, A. Bumblauskas) believe that in Lithuania there was a continuous process of peasants enslavement whose advance chronologically coincided with the apogee of new feudal reaction in typical second serfdom countries (in particular in the East German territory) ${ }^{27}$.

Lithuanian manorial serf economy in the 16th to the 18th centuries was oriented towards simple commercial production, which according to traditional Marxist historiography point of view shows a typical feudal economic nature. But diachronic comparative analysis of economic structures and trends of Western Europe manor of the 11th-15th centuries and manorial serf economy of Central Eastern Europe of the 16th18th centuries (particularly in Polish-Lithuanian Commonwealth) does not allow the Lithuanian (and Polish) manorial serf economy of the 16th18th centuries (which was affected by developing capitalist relations in Western Europe) to be qualified as typical feudal economies (such as Medieval Western Europe manor farms). In the 16th-18th centuries the purpose of economic production of Lithuanian (and Polish) manorial serf economy, due to price scissors economic phenomenon between inner and foreign markets (CWS influence) was oriented towards markets. Whereas the ordinary commercial output production was caused by the economic behavior of the owners of manorial serf economies, whose feature was not to invest the received funds in order to maximize the resources available, but to extend the consumption of the social elite. All this shows that Lithuanian manorial serf economies are not to be considered typical peripheral capitalism enterprises (in the strict sense of CWS concept) ${ }^{28}$. However,

\footnotetext{
${ }^{27}$ For more information, see Žiemelis, The Problem of the Application of the Term Second Serfdom in the History of Central Eastern Europe, 123-149.

${ }^{28}$ About the first time in historiography carried out diachronic comparative analysis of the 11th-15th c. Western European manor and the 16th-18th c. manorial-serf economy structures of Central Eastern Europe (especially of the Polish-Lithuanian Commonwealth) and trends of development, see Darius Žiemelis, 'XVI-XVIII amžiaus Abiejų Tautų Respublikos palivarko ūkis marksistiniu bei neoinstitucionalistiniu požiūriu' [The Manor Estate Economy of the Polish-Lithuanian Commonwealth in the 16th-18th Centuries from the Marxist and NeoInstitutionalist Perspectives], Lietuvos istorijos studijos 27 (2011): 11-38.
} 
looking at the economic development in Lithuania during manorial serf economy period (1557-1861) through the prism of peripheral capitalism concept ${ }^{29}$, the second serfdom features are most distinctly visible in Lithuania not during the 16th-18th centuries (as stated by I. Wallerstein) but during the second half of the 18th century to 1861, i.e. during the second development stage of manorial serf economy.

The second stage of economic development (from the second half of the 18th century to 1861) - was the maximum economic expansion of manorial serf economy by increasing the peasants socage ${ }^{30}$. In historiography this phenomenon is known as a renaissance of manorial serf economy ${ }^{31}$. Perhaps the main reason of this process was the industrial revolution in Western Europe commenced at the end of the 18th century, which again caused a demand in grain and other agricultural products on the international market ${ }^{32}$.

In Lithuania in the second half of the 18th century there were attempts to reform the farmstead economy based on the economic theory of

\footnotetext{
${ }^{29}$ See definition of peripheral capitalism in approach of CWS theory in reference no 24.

${ }^{30}$ In Lithuania, forced labor rate was approximately 2-3 days per week in the 17th-18th centuries. See Mečislovas Jučas, Baudžiavos irimas Lietuvoje [Deterioratio of Serdom in Lithuania] (Vilnius: Mintis, 1972), 40-141. Until the abolition of serfdom in 1861, the forced labor increased till 5 days per week. See Stanislovas Pamerneckis, Agrariniu santykiu raida ir dinamika Lietuvoje: XVIII a. pabaiga - XIX a. pirmoji pusé (statistine analizé) [The Evolution and Dynamics of Agrarian Relationships in Lithuania: The End of 18th Century - the First Half of 19th Century (Statistical Analysis)] (Vilnius: Vilniaus universiteto leidykla, 2004), 120. Many researchers note that in general up to the end of the 18th century in most Central Eastern European and Eastern European countries, corvée was an objective factor determining country's economy development. See, for example, Pamerneckis, Agrariniu santykiu raida ir dinamika Lietuvoje [The Evolution and Dynamics of Agrarian Relationships in Lithuania], 119; Robert Millward, 'The Early Stages of European Industrialization: Economic Organization under Serfdom', Explorations in Economic History 21, 4 (1984): 406-428.

31 For more information, see Jučas, Baudžiavos irimas Lietuvoje [Deterioratio of Serdom in Lithuania]: 103-104; Eligijus Raila, Ignotus Ignotas: Vilniaus vyskupas Ignotas Jokūbas Masalskis [Ignotus Ignotas: Vilnius Bishop Ignotas Jokūbas Masalskis] (Vilnius: Aidai, 2010), 187-188.

${ }^{32}$ See more Robert C. Allen, 'Economic Structure and Agricultural Productivity in Europe, 1300-1800', European Review of Economic History 4,1 (2000): 1-26; Jeffrey G. Williamson, 'Globalization and the Great Divergence: Terms of Trade Booms, Volatility and the Poor Periphery, 1782-1913', European Review of Economic History 12, 3 (2008): 355-391; Peter Mathias, 'The Emergence of a World Economy 1500-1914', VSWG: Vierteljahrschrift für Sozial- und Wirtschaftsgeschichte 74, 1 (1987): 1-17; Paul Bairoch, 'Free Trade and European Economic Development in the 19th Century', European Economic Review 3, 3 (1972): 211-245.
} 
physiocracy ${ }^{33}$. The research shows that the impact of Enlightenment ideas in the second stage of development of the Lithuanian economy gave, when compared to the economies of other Western European countries, the opposite result - the corvée farmstead economy was intensified. According to the statement of Eligijus Raila, after visiting many countries in Europe and becoming acquainted with some of the most advanced economic models of the second half of the 18th century Lithuanian nobles only imitated in their estates the principles of Western activities, i.e. they tried to insert the "pliable" principles of Enlightenment entrepreneurship and individual labor into the stagnant corvée farmstead economic system. So the structure of serfdom life that ignored personal freedom and guaranteed a strict hierarchy of society, in principle, was unable to absorb the economic potential based on the labor and responsibility of a free individual. One of the Lithuanian noblemen who represented the aforementioned spread of the economic process was A. Tyzenhauzas, who "intensified" the farm of royal economies by using serf labor. E. Raila very aptly defines such "intensification of the farm" as: "the reanimation of the corvée farmstead system using part of the technology of Western Europe and the latest farming methods" 34 .

After the collapse of Polish-Lithuanian Commonwealth in 1795, the biggest ethnographic part of Lithuania, for political reasons and because of the lack of ports, became colonial periphery of Russia (as a semi-peripheral CWS country). Lithuania as a double-colonial periphery orientated its economy not to the industry, but to supply of the raw materials to the centers of the Russian Empire and the Western market ${ }^{35}$. The agrarian nature of

\footnotetext{
${ }^{33}$ Its reception in Lithuania is tied to the wave of the "new agriculture" that arose at the junction of the 17th-18th c. in the Norfolk county of England, which reached the PolishLithuanian Commonwealth from France somehow delayed. According to the statement by E. Raila, that the reception of this theory was encouraged not so much by the unique view of the elite of the Polish-Lithuanian Commonwealth toward this product of political economy thought as one of the possible options for European culture but as the total invasion by the culture of France bringing this physiocratic idea as an integral element of this culture. More about the origin and evolution of physiocracy theory and the configuration of physiocracy in Lithuania, see Raila, Ignotus Ignotas, 117-144.

${ }^{34}$ Raila, Ignotus Ignotas, 188.

35 See more Darius Žiemelis, 'The Socio-Economic History of Lithuania from the 16th to the 19th Century (until 1861) from the Perspective of Economic Development Concepts', Revista Română de Studii Baltice și Nordice / The Romanian Journal for Baltic and Nordic Studies 5, 2 (2013),
} 
Lithuanian economy increased even more. As shown by research of Stanislovas Pamerneckas - the expansion of manorial serf economy from 1795 until 1861, by increasing the peasants' socage reached the maximum expansion limits ${ }^{36}$. The final establishment of manorial serf economy is evidenced by the fact that from the second half of the 18th century into 1861 Lithuanian export structure is dominated by grains, mainly grown in manorial serf economies unlike during the first economic development stage of Lithuania (middle of the 16th to the second half of the 18th centuries) ${ }^{37}$. These are the features of the so-called second serfdom. As stated by S. Pamerneckis: "Lithuania, together with the Belorussian territories was the most conserved nook of serfdom relations in the European part of the Russian Empire" 38 .

Lithuanian economic structure and evolution (in the second half of the 18th century up to 1861) in the context of world history gets nearest to the peripheral capitalist economic "ideal model" highlighted in CWS concept ${ }^{39}$. Consumerist use of capital and weak economic involvement in international trade, which was the typical behavior of the owners of manorial serf

80-82; Zenonas Norkus, ‘Kapitalizmo raidos Lietuvoje bruožai ir etapai (iki 1940 m.) postmarksistiniu požiūriu [The Features and Stages of the Capitalist Development of Lithuania (before 1940) from the Post-Marxist Viewpoint]', Lietuvos istorijos studijos 29 (2012), 21-22.

36 See more Pamerneckis, Agrariniu santykiu raida ir dinamika Lietuvoje [The Evolution and Dynamics of Agrarian Relationships in Lithuania], 119-121.

${ }^{37}$ For more information about the commodity structure of Lithuania's exports and imports in the second half of the 18th c. - 19th c. (until 1861), seе Витовт Ю. Меркис, 'Экспорт зерна и иьна из Дитвы в 1795-1861 гг.', in: Ежегодник по аграрной истории Восточной Европы 1963 г.: (доклады и сообщения шестой сессии межреспубликанского симпозиума по аграрной истории, состоящегося в г. Вильнюсе с 19 по 24 сентября 1963 г.) (Вильнюс, 1964): 436-447; Žiemelis, 'The Structure and Scope of the Foreign Trade of the Polish-Lithuanian Commonwealth in the $16^{\text {th }}$ to $18^{\text {th }}$ Centuries: The Case of the Grand Duchy of Lithuania', 91-123; Leonid Źytkowicz, 'Kilka uwag o handlu zewnętrznym Wielkiego Księstwa Litewskiego w ostatnich latach Rzecypospolitej', Zapiski Historyczne 41, 2 (1976): 87-101.

38 Pamerneckis, Agrariniu santykiu raida ir dinamika Lietuvoje [The Evolution and Dynamics of Agrarian Relationships in Lithuania], 120.

${ }^{39}$ For more information about the typological diagnostics of Lithuanian social and economic history of the 16th-19th centuries (up to 1861) in the context of the world's history, in terms of the most influential economic development concept, see Žiemelis, 'The Socio-Economic History of Lithuania from the 16th to the 19th Century (until 1861) from the Perspective of Economic Development Concepts', 57-90. 
economies, prevented Lithuania to fully become a peripheral capitalism zone. The qualitative breaking point occurred during the after-reform period (i.e. after the abolition of serfdom in 1861). As shown by researches of Z. Norkus economic development period of Lithuania in 1861-1914 already fully complies with the peripheral, colonial capitalism economic type ${ }^{40}$.

\section{The Comparison of Economic Structures and Development} Trends of the Lithuanian Manorial Serf Economy and Latin America Hacienda in the Second Half of the 18th Century - the Second Half of the 19th Century

It would be best to start with definitions of manorial serf economy and hacienda as economic organization systems in order to compare the economic structures and development trends of Lithuanian manorial serf economy and Latin American hacienda during the period under scrutiny. The first model of manorial serf economy as an economic organization based on Polish manorial serf economy development of the 16th-18th centuries was presented by one of the most famous Polish economic historian Witold Kula in 1962, in his treatise "An Economic Theory of the Feudal System. An Attempt of a Model"41, now considered a classical text. W. Kula assigns the following features to manorial serf economy as a socio-economic unit: 1) the extensity of the economy: the size of the area cultivated determined the size of the harvest, while the area - the quantity of sleds of the peasants working in the field of the landlord; 2) the pursuit of the optimal (for the benefit of the master) relationship between the land of the master and the plots allowed for the peasants; 3 ) the consumer use of the master's appropriated surcharge product (its exchange on the market into other consumer products); 4) meager investments, i.e. the simple reproduction of the farm - the

\footnotetext{
${ }^{40}$ For more information, see Norkus, 'Kapitalizmo raidos Lietuvoje bruožai ir etapai (iki 1940 m.) postmarksistiniu požiūriu [The Features and Stages of the Capitalist Development of Lithuania (before 1940) from the Post-Marxist Viewpoint]', 22-25.

${ }^{41}$ Witold Kula, Teoria ekonomiczna ustroju feudalnego: Próba modelu (Warszava: Państwowe Wydawnictwo Naukowe, 1962). Further we shall rely on the English version of this work (Witold Kula, An Economic Theory of the Feudal System: Towards A Model of the Polish Economy 1500-1800 / Translated from the Polish by L. Garner, Presentation by F. Braudel (London: New Left Books, 1976)), because it takes into account the comments of critics.
} 
landowner, even if he invests the assets in order to increase the added product, that was usually performed by converting village fields into the master's plowed land or increasing the corvée of these very peasants; 5) the very large variation in the size of the marketable production of the farmstead manor farm, mainly determined by the yield of the harvest and only partially by market demand. The core conclusion of W. Kula says: although the manorial-serf economy (i.e., late feudalism "enterprise") was related to some extent to the domestic and international markets, its nature was mainly subsistence ${ }^{42}$.

The first definition of hacienda as a system of economic organization of agriculture was provided by American anthropologists Eric R. Wolf and Sidney W. Mintz. Hacienda is an estate engaged in agriculture, managed by the land owner, who employs the dependent labor force. Because of the deficiency of working capital, the production made by estate is intended for small-scale (i.e. domestic) market. This production is employed not only for capital accumulation, but also to support the status aspirations of the owner ${ }^{43}$. The similarities and differences of hacienda economy and manorial serf economy become even more visible not only when comparing them together, but also when comparing them with plantation - which was similar in type, but displayed a different organization of the agricultural system in the Americas. According to Eric R. Wolf and Sidney W. Mintz the plantation is an estate engaged in agriculture, managed by the owners (who usually organize it as a corporation), based on the work of dependent labor force. Because of the estate's ownership of large capital, the goods produced by estate are exclusively focused on foreign market, and products are employed primarily to further capital accumulation without reference to the status needs of the owners ${ }^{44}$. The fundamental difference lies in the labor force which is being used. Hacienda is based on serfdom, and the plantation - on slavery production. Hacienda and plantation economic systems are the result of global economy and their evolution which appeared in the 16th

\footnotetext{
${ }^{42}$ See more Kula, An Economic Theory of the Feudal System: Towards A Model of the Polish Economy 1500-1800, 50-83.

${ }^{43}$ Eric R. Wolf and Sidney W. Mintz, 'Haciendas and Plantations in Middle America and the Antilles', Social and Economic Studies 6, 3 (1957), 380.

${ }^{44}$ Wolf and Mintz, 'Haciendas and Plantations in Middle America and the Antilles', 380.
} 
century in the Americas because they are focused on production supply to the market ${ }^{45}$.

Latin American hacienda and Lithuanian manorial serf economy systems are classified as land management systems whose main feature is the large area of land owned by the state or on the landowner rights. Here the first similarity can be seen between Latin American hacienda and Lithuanian manorial serf economy systems in terms of land use rights. In the second half of the 18th century to the second half of the 19th century in Lithuania as in Latin America countries, the land was the property of the state or landowners. In order to use the land, first and foremost, the peasants were required to pay socage. From am institutionalist point of view in hacienda system there was no implicit exchange agreement between landowners and peasants, which was the basis of Western Europe manor system in the 11th-15th centuries ${ }^{46}$. Like the manorial serf economy, hacienda system was based on the domination of the landowner over peasants. On the other hand, similarly to the manorial serf economy model, in hacienda peasant's (living in sparsely populated area and far away from the city) dependence on landlord meant some sort of protection of their farm against total collapse ${ }^{47}$.

\footnotetext{
${ }^{45}$ For more information about comparative analysis of hacienda and plantations systems, see Wolf and Mintz, 'Haciendas and Plantations in Middle America and the Antilles', 380-412; Sidney W. Mintz, 'The Culture History of a Puerto Rican Sugar Cane Plantation: 1876-1949', Hispanic American Historical Review 33, 2 (1953): 224-251.

${ }^{46}$ For more information about the analysis of Western Europe manor structure and trends of development of the 11th-15th centuries in terms of institutionalism, see Douglass C. North and Robert Paul Thomas, 'The Rise and Fall of the Manorial System: A Theoretical Model', Journal of Economic History 31, 4 (1971): 777-803; North and Thomas, 'An Economic Theory of the Growth of the Western World', Economic History Review 23, 1 (1970): 1-17.

${ }^{47}$ For more information about Latin hacienda, see, for example, Wolf and Mintz, 'Haciendas and Plantations in Middle America and the Antilles', 391-393. For more information about Lithuanian manorial serf economy, see, Tamara Bairašauskaitė, 'Bajoro santykis su dvaru XIX a. pirmoje pusejje: Mykolo Juozapo Römerio (1778-1853) patirtys' [The Relationship of A Noble to His Estate in the First Half of the Nineteenth Century: Mykolas Juozapas Rőmeris (1778-1853)], Lietuvos istorijos metraštis 1, 2005 (2006): 63-82; Mečislovas Jučas, 'Prekyba Lietuvos kaime XVIII a.', Iš Lietuviu kultūros istorijos 4 (1964): 109-122. This "patronizing" presence of connection between landlord and peasant belonging to him radically separates the manorial serf economy and hacienda from plantation economy model. In the latter a person belonging to landlord - per se did not mean anything. For example, the plantation owners as a means to curb undisciplined work in respect of dependent person often used the
} 
What causes determined and in what ways was achieved the privileged landowner's position over peasant in the second half of the 18th century to the second half of the 19th century in Latin American countries? Reasons and implementation methods in Latin America were almost similar to the processes which caused manorial serf economy system in Central Eastern Europe in the 16th-18th centuries. Due to the weakness of the cities, the shortage of labor force, large areas of uncultivated land and involvement in the international division of labor in peripheral status in the 16th-18th centuries in Central Eastern Europe region (including Lithuania) the social balance of power tilted in favor of nobility, which allowed to maximize peasant serfdom dependence on the manor ${ }^{48}$. As we have seen, these processes gained even more momentum in the second half of the 18th century - the second half of the 19th century in the social economic development of Lithuania, which manifested as the second serfdom. There are assumptions that the emergence of Latin American landowners was not only due to weak cities, large areas of uncultivated land and involvement in the international division of labor in peripheral status, but also the colonial institutional environment. Majority of hacienda owners were either originating from Europe, or loyal to the colonial policy ${ }^{49}$.

Latin American hacienda of the second half of the 18th century - the second half of the 19th century as an economic organization system emerged from the encomienda economic system which existed in Latin America in the 16th - middle of the 18th centuries. The analogue of encomienda should be regarded Western European manor economic model from the 11th15th centuries. Ecomienda system is the result of imported manor economic

death penalty. See Wolf and Mintz, 'Haciendas and Plantations in Middle America and the Antilles', 395.

${ }^{48}$ For more information, see Žiemelis, Abieju Tautu Respublikos socialiné ekonomine raida XVIXVIII amžiuje analize [Social Economic Development of the Republic of the Two Nations in the 16th18th Centuries], 168-171.

${ }^{49}$ See, for example, François Chevalier, Land and Society in Colonial Maxico: The Great Hacienda (Berkeley: University of Colifornia Presws, 1963); Stanley J. Stein and Barbara H. Stein, The Colonial Heritage of Latin America: Essays on Economic Dependence in Perspective (New York: Oxford University Press, 1970); Magnus Mörner, 'Economic Factors and Stratification in Colonial Spanish America with Special Regard to Elites', Hispanic American Historical Review 63, 2 (1983): 335-369. 
model from Spain and Portugal to Latin America ${ }^{50}$. This system started to become an inefficient land management form since the second half of the 17th century, until finally completely disappears at the end of the 18th century and was replaced by hacienda economic system ${ }^{51}$. Perhaps the main reasons which caused the transformation of ecomienda economic system to hacienda economic system were internal. One of the most important reasons was the drastically decreased number of Indians because of colonial oppression until the 17th century and the demographic trend of decline of the Indian population continued unabated ${ }^{52}$. Precisely until the middle of the 17th century Indians were the main labor force in the most important branch of Latin American ecomienda economy - mining ${ }^{53}$. The rest of the labor force was also difficult to maintain, because due to the increased workload it migrated to territories where working conditions were

50 For more information about Latin American ecomienda system, see David Weeks, 'European Antecedents of Land Tenures and Agrarian Organization of Hispanic America', Journal of Land \& Public Utility Economics 23, 1 (1947): 60-75; Weeks, 'The Agrarian System of the Spanish American Colonies', Journal of Land \& Public Utility Economics 23, 2 (1947): 153168; James Lockhart, 'Encomienda and Hacienda: The Evolution of the Great Estate in the Spanish Indies', Hispanic American Historical Review 49, 3 (1969): 411-429. The establishment and functioning of ecomienda did not change radically the lifestyle of Indian peasants, i. e. relatively posed no threat to their extinction as society. Meanwhile the establishment and evolution of hacienda radically transformed Indian society to the agricultural working class, which anticipated the extinction process of Indians as the society. See more Robert G. Keith, 'Encomienda, Hacienda and Corregimiento in Spanish America: A Structural Analysis', Hispanic American Historical Review 51, 3 (1971): 431-446; Charles Gibson, The Aztecs under Spanisli Rulle: A History of the Indians of thle Valley of Mexico, 1519-1810 (Stanford: Stanford University Press, 1964).

${ }^{51}$ See David M. Jones, 'The Importance of the "Hacienda" in 19th Century Otumba and Apan, Basin of Mexico', Historical Archaeology 15, 2 (1981): 87-116; Eric Van Young, Hacienda and Market in Eighteenth-Century Mexico: The Rural Economy of the Guadalajara Region, 1675-1810 (Berkeley: University of California Press, 1981); Karen Spalding, 'Hacienda-Village Relations in Andean Society to 1830', Latin American Perspectives 2, 1 (1975): 107-121; Warren Dean, 'Latifundia and Land Policy in Nineteenth-Century Brazil', Hispanic American Historical Review 51, 4 (1971): 606-625; Chevalier, Land and Society in Colonial Maxico...

52 For example, in one of the largest countries in Latin America - Mexico since 1521 until 1605, number of the Indians fell by about 95 percent, because of the Spanish economic exploitation and political oppression. See Brzechczyn, $O$ wielości linii rozwojowych w procesie historycznym. Próba interpretacji ewolucji społeczeństwa meksykańskiego, 339.

${ }^{53}$ For more information, see Peter J. Bakewell, Silver Mining and Society in Colonial Mexico. Zacatecas 1546-1700 (Cambridge: Cambridge University Press, 1971). 
relatively more favorable. The conditions were caused by implicit exchange contract which existed between the landowners and the Indian peasants. Another internal cause was the increase in demand of the agricultural production on the domestic market. Demand for agricultural production and its production cost was increased by development of cities, which grew mainly because of the increase of non-Indian origin population ${ }^{54}$. There emerged a problem of ensuring the labor needed in the agricultural sector. External reasons also contributed to the internal reasons in the process of transformation of encomienda system to hacienda. One of the most important external reasons was global crisis of the middle of the 17th century, which negatively affected the already mentioned main agricultural sector in Latin America - mining ${ }^{55}$. Drop in prices of gold and silver raw materials on the international market forced the suppliers to increase the production volume. That could be done only by further exploitation of the limited labor force. On the other hand, the decline in mining changed the direction of capital investment. Mine owners began to sell the mines and invested the received capital into purchasing and establishing large estates, which supplied agricultural production to increased urban markets and mining regions ${ }^{56}$. Another external reason which significantly accelerated the establishment and intensification of hacienda system was world trade conjuncture, which changed from the

\footnotetext{
54 See more, for example, Ida Altman, 'Spanish Society in Mexico City after the Conquest', Hispanic American Historical Review 71, 3 (1991): 413-445; Eric Van Young, 'Urban Market and Hinterland: Guadalajara and Its Region in the Eighteenth Century', Hispanic American Historical Review 59, 4 (1979): 593-635; Warwick Bray, 'The City State in Central Mexico at the Time of the Spanish Conquest', Journal of Latin American Studies 4, 2 (1972): 161-185; Richard Boyer, 'Mexico in the Seventeenth Century: Transition of a Colonial Society', Hispanic American Historical Review 57, 3 (1977): 455-478.

55 See more Woodrow Borah, New Spain's Centutry of Depression (Berkeley: University of California Press, 1951). See also David A. Brading, Miners and Merchants in Bourbon Mexico, 1763-1810 (Cambridge: Cambridge University Press, 1971); David A. Brading and Harry E. Cross, 'Colonial Silver Mining: Mexico and Peru', Hispanic American Historical Review 52, 4 (1972): 545-579.

${ }^{56}$ See Stanley J. Stein and Barbara H. Stein, The Colonial Heritage of Latin America: Essays on Economic Dependence in Perspective, 38. See also Magnus Mörner, 'The Spanish American Hacienda: A Survey of Recent Research and Debate', Hispanic American Historical Review 53, 2 (1973), 190.
} 
second half of the 18th century. The Industrial Revolution in Western Europe caused an increased demand of agricultural production (particularly in cotton, sugar, coffee, cereal) on the world market ${ }^{57}$. The need of those products on the world market triggered social and economic transformations in the Americas in 1780-1888. It was the period of already mentioned second slavery whose main feature was an intensification of repressive labor (especially slave labour) in new territories of American economic world (South Brazil, Cuba and US Southern states) and lasted until the abolition of slavery in Brazil, in $1888^{58}$. Latin American landowners in order to adapt to the international market conjuncture, solved the labor force problem by choosing hacienda economy type, which focused on the serfdom production method. As in the Central Eastern Europe, the labor force problem in Latin America was solved in two ways: 1) by tying the peasants to the manor land, especially through debt and forced recruitment ('predial serfdom') and 2) by expropriating their lands ${ }^{59}$.

\footnotetext{
57 See more Klas Rönnbäck, 'Consumers and Slavery: Diversified Markets for Plantation Produce and the Survival of Slavery in the Nineteenth Century', Review (Fernand Braudel Center) 31, 1 (2010): 69-88; Simon Miller, 'Wheat Production in Europe and America: Mexican Problems in Comparative Perspective, 1770-1910', Agricultural History 68, 3 (1994): 16-34.

58 See more Tomich and Zeuske, 'Introduction, The Second Slavery: Mass Slavery, WorldEconomy, and Comparative Microhistories', 91-100; Anthony E. Kaye, 'The Second Slavery: Modernity in the Nineteenth-Century South and the Atlantic World', Journal of Southern History 75, 3 (2009): 627-650; Enrico Dal Lago, 'Second Slavery, Second Serfdom, and Beyond: The Atlantic Plantation System and the Eastern and Souther European Landed Estate System in Comparative Perspective, 1800-60', Review (Fernand Braudel Center) 32, 4 (2009): 391-420; Laird W. Bergad, The Comparative Histories of Slavery in Brazil, Cuba, and the United States (New York: Cambridge University Press, 2007). See also Stuart B. Schwartz, 'Indian Labor and New World Plantations: European Demands and Indian Responses in Northeastern Brazil', American Historical Review 83, 1 (1978): 43-79.

59 See Kay, 'Comparative Development of the European Manorial System and the Latin American Hacienda System', 81; Wolf and Mintz, 'Haciendas and Plantations in Middle America and the Antilles', 390-391. For more information about converting the peasants into serfs in Latin America, see Arnold J. Bauer, 'Rural Workers in Spanish America: Problems of Peonage and Oppression' Hispanic American Historical Review 59, 1 (1979): 34-63; Friedrich Katz, 'Labor Conditions on Haciendas in Porfirian Mexico: Some Trends and Tendencies', Hispanic American Historical Review 54, 1 (1974): 1-47.
} 
Two groups of countries are highlighted when talking about the origin and evolution intensity of hacienda in Latin America ${ }^{60}$. The first group includes Latin American countries where hacienda system was created the latest and its evolution was relatively slow. These countries were characterized by multiple population, fertile soils and relatively high standard of living, strong local communities which actively fought for their rights. Therefore it was harder for the landowners of this group of countries (including Peru, Bolivia, Ecuador, Mexico and Guatemala) to create large estates and supply them with forced labor. The countries belonging to the second group had little population density, weak communities, underdeveloped agriculture. Therefore, in this group of countries (Chile, Argentina, Uruguay and Brazil) the peasant serfdom process was considerably faster, which caused (compared with the first group of countries) the early establishment and intensive development of hacienda system. The evolution of agrarian relations and dynamics in Lithuania in the second half of the 18th century - the second half of the 19th century are more similar to the evolution of agrarian relations and dynamics of the second group countries - Chile, Argentina, Uruguay and Brazil. Lithuania during the investigation period also had rare population density, low agricultural productivity, the absence of unified peasant resistance against landowners and lack of deep traditions of fighting for their rights. We must establish thorough comparative research (which would be the object of another research) in order to determine more specifically which country (Chile, Argentina, Uruguay and Brazil) had agrarian relations evolution and dynamics most similar to the agrarian evolution of relations and dynamics of Lithuania ${ }^{61}$. Here we will only remark that the export structure was

\footnotetext{
60 See Kay, 'Comparative Development of the European Manorial System and the Latin American Hacienda System', 80.

${ }^{61}$ Furthermore, C. Kay who compared Europe manor and Latin America hacienda systems during the investigative period finds most similarities between the development of agrarian relations in Prussia and Chile. See Kay, 'Comparative Development of the European Manorial System and the Latin American Hacienda System', 84-86. For more information about the similarities of development of agrarian relations of Chile and Prussia, see Arnold J. Bauer, 'The Hacienda El Huique in the Agrarian Structure of Nineteenth-Century Chile', Agricultural History 46, 4 (1972): 455-470; Bauer, 'Chilean Rural Labor in the Nineteenth Century', American Historical Review 76, 4 (1971): 1059-1083. For more information about development
} 
dominated by grain in both Lithuania and Chile in the first half of the 19th century ${ }^{62}$.

The biggest structural similarity between the Lithuanian manorial serf economy and hacienda economy of Latin American countries at the time must be regarded the predominance of ordinary commercial production. The orientation of hacienda economy to the ordinary commercial production was not only because of the lack of working capital ${ }^{63}$, but also because of the economic behaviour of landowners. Hacienda manor economy acquired labor force and land by non-economic means, so it was not the goal of their owners, unlike the owners of slavery plantations economies, to maximize profits and invest it in the expansion of production. The revenues were used for prestigious consumption, to maintain customer network, to build objects of non-production function. Having in mind the consumerist use of income of manor economy during the analyzed period we can deduce the similarity

of agrarian relations in Prussia, in 19th century, see Bowman, Masters and Lords: Mid-19thCentury U.S. Planters and Prussian Junkers...

${ }^{2}$ Seе Меркис, 'Экспорт зерна и иьна из Аитвы в 1795-1861 гг.' , 436-447; Kay, ‘Comparative Development of the European Manorial System and the Latin American Hacienda System', 82.

${ }^{63}$ During the investigative period hacienda economy was not the only economy type in Latin America. For example, slavery coffee and cotton plantations existed in the south of Brazil. The emergence and domination of hacienda economy type in respect of plantation economy in Latin America, not only due to the reasons mentioned (i.e. weak cities, shortage of labor force, large areas of uncultivated land and involvement in the international division of labor on the status of periphery, the colonial institutional environment), but also the lack of capital. According to Eric R. Wolf and Sidney W. Mintz, namely the disposable capital was the essential criteria, finally leading to the dominance of hacienda economy in relation to plantation economy in Latin America. Slavery plantation farms oriented to a capitalist commercial production were established by foreign capital, mostly by corporations of few owners. This type of economy required working capital in order to create and ensure an efficient infrastructure (e.g. to improve roads in order to to realize the products in foreign markets), constantly update agro-technology and means of production (e.g., acquiring the slaves as the main labor force, land purchase). It was necessary to invest a lot, therefore the owners of slave plantations were interested not only to recover the invested capital, but also to increase it. That could be achieved only by capitalist commercial production. For more information about the capital impact on creation and development of hacienda and plantation, see Wolf and Mintz, 'Haciendas and Plantations in Middle America and the Antilles', 386-387 and 396-397. 
which exists between Lithuanian, Latin American countries and the Prussian landowners ${ }^{64}$.

The efficiency of hacienda economy was partly based on monopoly conditions rather than on the market economy conditions. Landowners settled in the vicinity of "normal", i.e. city (local) market artificially created the landlord's "patrimonial market" where the peasants belonging to them were forced to buy the manor economy products and services ${ }^{65}$. On the other hand, serfdom labor and forced recruitment of peasants played the important role in ensuring the competitiveness of the manor farm production in normal market through the reduction of labor costs ${ }^{66}$. Here we see another similarity between manorial serf economy and hacienda and their distinction from the slave plantation economy. Compared to the slavery plantation economy, manorial serf economy and hacienda were less dependent on international trade conjuncture, as they were less involved in it. Hacienda economies of Latin American countries and Lithuanian manorial serf economies were oriented to agricultural production (particularly bovine animal, corn and grain cultivation) and were little involved in international trade. Only large hacienda economies were an exception. There were few large hacienda economies which were exportoriented on single Latin American country scale. The exception is Mexico, which, during the investigation period, had the biggest number of large

\footnotetext{
${ }^{64}$ For more information about the consumerist behavior of Lithuanian, Latin American and Prussian landowners in the second half of the 18th century - the second half of the 19th century, see Raila, Ignotus Ignotas, 165-203; Pamerneckis, Agrariniu santykiu raida ir dinamika Lietuvoje, 111; Simon Miller, 'Mexican Junkers and Capitalist Haciendas, 1810-1910: The Arable Estate and the Transition to Capitalism between the Insurgency and the Revolution', Journal of Latin American Studies 22, 2 (1990): 229-263; Wolf and Mintz, 'Haciendas and Plantations in Middle America and the Antilles', 386-389; Mörner, 'The Spanish American Hacienda: A Survey of Recent Research and Debate', 205-207; Bowman, Masters and Lords: Mid-19th-Century U.S. Planters and Prussian Junkers...

${ }^{65}$ See Wolf and Mintz, 'Haciendas and Plantations in Middle America and the Antilles', 388; Kay, 'Comparative Development of the European Manorial System and the Latin American Hacienda System', 80-83.

${ }^{66}$ See Bauer, 'Rural Workers in Spanish America: Problems of Peonage and Oppression', 4859; Alan Richards, 'The Political Economy of Gutswirtschaft: A Comparative Analysis of East Elbian Germany, Egypt, and Chile', Comparative Studies in Society and History 21, 4 (1979), 485486.
} 
haciendas, oriented to foreign markets, compared to other Latin American countries $^{67}$. Large extent of involvement of Latin American haciendas in international trade, causing their peripheral position in the world hierarchical division of labor, is detected only from the seventies of the 19th century ${ }^{68}$.

Serfdom production method was also supported by colonial institutional environment of compared countries. In 1795, after the incorporation into the Russian Empire Lithuania became subordinate to Russia's state policy of serfdom ${ }^{69}$. Compared to Lithuania, Latin American countries were Europe's (primarily of Spain and Portugal) colonies already from 16th century. The liberation of Latin American countries from colonial dependence began only in the first half of the 19th century. The presence of colonial environment or liberation from it caused various peasant movement opportunities in Latin America and Lithuania. Because of the colonial dependence of Russian empire, the manorial serf economy in Lithuania intensified and peasants were even more tied to the estate lands. At that time, peasant movement possibilities, which existed until the end of serfdom in 1861, were almost eliminated. Meanwhile, in Latin America since the twenties of the 19th century (because of liberation of countries from colonial dependence) peasant freedom of movement increased. For example, peasants of Peru, Bolivia, Ecuador, Mexico and Guatemala haciendas, in order to achieve better living conditions, could move more freely from one estate to another or to look for such conditions in the city ${ }^{70}$.

\footnotetext{
${ }^{67}$ See primarily Chevalier, Land and Society in Colonial Maxico: The Great Hacienda; Alan Knight, 'Land and Society in Revolutionary Mexico: The Destruction of the Great Haciendas', Mexican Studies / Estudios Mexicanos 7, 1 (1991): 73-104; Miller, 'Mexican Junkers and Capitalist Haciendas, 1810-1910: The Arable Estate and the Transition to Capitalism between the Insurgency and the Revolution', 229-263.

68 See Mörner, 'The Spanish American Hacienda: A Survey of Recent Research and Debate', 205-207. See also Miller, 'Wheat Production in Europe and America: Mexican Problems in Comparative Perspective, 1770-1910, 16-34.

${ }^{69}$ For more information about serfdom and its policy in Russian empire, see David Moon, 'Reassessing Russian Serfdom', European History Quarterly 26, 4 (1996): 483-526; Kolchin, Unfree Labor: American Slavery and Russian Serfdom.

70 See Kay, 'Comparative Development of the European Manorial System and the Latin American Hacienda System', 83. See also Katz, 'Labor Conditions on Haciendas in Porfirian Mexico: Some Trends and Tendencies', 1-47.
} 
In terms of traditional Marxist historiography, the predominance of ordinary commercial production shows a typical feudal economic nature. However, the production was market-oriented in Lithuanian manorial serf economy, as well as in Latin American haciendas. As a result the Lithuanian manorial serf economy organization and Latin American hacienda economic organization cannot be considered as typical feudal economic system, because of world economic nature that existed during the investigative period. When examining the cases of Lithuanian manorial serf economy and Latin America hacienda we are faced with problem of qualification of hacienda economy system ${ }^{71}$.

In historiography there are a various names of the Latin American hacienda system of the second half of the 18th century - the second half of the 19th century: embryonic stage of capitalism, transition period from feudalism to capitalism and etc. ${ }^{72}$. However, we believe that Latin American

\footnotetext{
${ }^{71}$ Furthermore, there are no disputes in historiography concerning the classification of the slavery plantation economy as capitalist enterprise. See Wolf and Mintz, 'Haciendas and Plantations in Middle America and the Antilles', 396-407; Eugene D. Genovese, 'The Significance of the Slave Plantation for Southern Economic Development', Journal of Southern History 28, 4 (1962): 422-437. It should be noted that econometric history destroyed the thesis that became mass historical consciousness myth that slavery plantation economy in Southern states of America, in the eve of the Civil War (1861-1865) was in the state of stagnation. It would seem the war was "superfluous", slavery would have become extinct by itself for purely economic reasons. See Robert W. Fogel and Stanley L. Engerman, Time on the Cross: The Economics of American Negro Slavery (Boston: Toronto, 1974).

72 See Andre G. Frank, Capitalism and Underdevelopment in Latin America: Historical Studies of Chile and Brazil (New York: Monthly Review Press, 1967); Eric J. Hobsbawm, 'A Case of NeoFeudalism: La Convencion, Peru', Journal of Latin American Studies 1, 1 (1969): 31-50; Ernesto Laclau, 'Feudalism and Capitalism in Latin America', New Left Review 67 (1971): 1938; Kyle Steenland, 'Notes on Feudalism and Capitalism in Chile and Latin America', Latin American Perspectives 2, 1 (1975): 49-58; Colin Henfrey, 'Dependency, Modes of Production, and the Class Analysis of Latin America', Latin American Perspectives 8, 3/4 (1981): 17-54; Gustavo Rodríguez, 'Accumulation, Capitalism, and Precapitalistic Agriculture in Bolivia (1870-1885)', Latin American Perspectives 7, 4 (1980): 50-66; Ruggiero Romano, 'American Feudalism', Hispanic American Historical Review 64, 1 (1984): 121-134; Steve J. Stern, 'Feudalism, Capitalism, and the World-System in the Perspective of Latin America and the Caribbean', American Historical Review 93, 4 (1988): 829-872; Miller, 'Mexican Junkers and Capitalist Haciendas, 1810-1910: The Arable Estate and the Transition to Capitalism between the Insurgency and the Revolution', 229-263; Knight, Land and Society in Revolutionary Mexico: The Destruction of the Great Haciendas', 73-104; Rani T. Alexander, 'Haciendas and
} 
hacienda economic system as well as Lithuanian manorial serf economy from the second half of the 18th century to the second half of the 19th century was neither a typical feudal economy nor a typical peripheral capitalist enterprise (CWS concept in the strict sense) and had peripheral capitalist features. According to the most famous Latin American hacienda researchers Mörner Magnus and Eric Van Young: hacienda as the economic system had capitalist, but as a social system - feudal character ${ }^{73}$.

\section{Conclusions}

The existence of serfdom economy in Lithuania until 1861 is considered in historiography as an anachronism in the context of Western European economic system. However a comparative perspective highlights its "normality" in backwardness countries. We tried to reveal that serfdom economy in Lithuania and in Latin American countries during the second half of the 18th century to the second half of the 19th century was the only possible economic development factor.

The research showed different domination prehistory of analyzed economic systems. The second half of the 18th century up to the second half of the 19th century was the period of domination and intensification of the Lithuanian manorial serf economy which was the continuation of manorial serf economy of the 16th century - middle of the 18th century, which had second serfdom features. Hacienda economy of the second half of the 18th century - the second half of the 19th century is the result of transformation of Latin American encomienda system of the 16th - middle of the 18th century, the analogue of which could be considered the Western Europe manorial economy model of the 11th-15th centuries. It was the Industrial Revolution which caused the domination of manorial serf economy and hacienda economic systems during the surveyed period which triggered second-slavery in Americas. Latin American landowners, lacking working capital for acquiring means of production (such as slaves) and

\footnotetext{
Economic Change in Yucatán: Entrepreneurial Strategies in the Parroquia de Yaxcabá, 17751850', Journal of Archaeological Method and Theory 43 / 4 (1997): 331-351.

73 See Mörner, 'The Spanish American Hacienda: A Survey of Recent Research and Debate', 210-212; Eric Van Young, 'Mexican Rural History since Chevalier: The Historiography of the Colonial Hacienda', Latin American Research Review 18, 3 (1983), 21.
} 
trying to adapt to the international market conjuncture, solved labor force problem by selecting hacienda economy type, which focuses on the serfdom production method.

The analysis showed that Lithuanian manorial serf economy and Latin America hacienda economic systems of the second half of the 18th century second half of the 19th century were based on the absolute domination of landowners (both public and private) over the peasants. First and foremost the peasants were required to pay socage for the use of land. The emergence of Latin American landowners was not only due to weak cities, large areas of uncultivated land and involvement in the international division of labor on the status of periphery (the emergence of Lithuanian landowners was caused by the same reason), but also the colonial and institutional environment. Most hacienda owners were either originating from Europe, or loyal to the colonial policy.

The comparative analysis concerning structures and development trends of Lithuanian manorial serf economy and Latin America hacienda economy of the second half of the 18th century - second half of the 19th century does not allow to qualify these economic systems as being affected by evolving capitalist relations of Western Europe. They were neither a typical feudal economy (like medieval Western Europe manor economy), nor genuine peripheral capitalist enterprises (in the strict sense of neo-Marxist CWS concept). Both agricultural systems were dominated by ordinary commercial production, which in the traditional Marxist perspective is considered to be a typical feudal economy. However, the production of Lithuanian manorial serf economy and Latin America hacienda economy caused by consumerist economic logic of their owners was market-oriented because of the impact of world economy. Lack of capital to organize large-scale production led to weak involvement of these economies on the international market. All these traits suggest that Lithuanian manorial serf economy and Latin America hacienda economic systems of the second half of the 18th century - the second half of the 19th century had peripheral capitalist features (i.e. serfdom labor use in the production, political and economic colonial dependency, peripheral status in the global division of labor, a constant residual manorial serf economy and 
hacienda economy production in the export structure), which were intertwined with feudal economic system residues (one of them consumerist use of capital by the owners of manorial serf economies and haciendas).

\section{References:}

Alexander, Rani T. 'Haciendas and Economic Change in Yucatán: Entrepreneurial Strategies in the Parroquia de Yaxcabá, 1775-1850', Journal of Archaeological Method and Theory 4, 3/4 (1997): 331-351.

Allen, Robert C. 'Economic Structure and Agricultural Productivity in Europe, 1300-1800', European Review of Economic History 4, 1 (2000): 126.

Altman, Ida. 'Spanish Society in Mexico City after the Conquest', Hispanic American Historical Review 71, 3 (1991): 413-445.

Anušauskas, Arvydas. 'Ginkluotos kovos dèl Baltijos šalių ir Vakaru Ukrainos nepriklausomybès lyginamoji analizė [Comparative Analysis of Armed Resistance for Independence in the Baltic Countries and Ukraine]', Genocidas ir rezistencija 2 (1997): 14-18.

Antanaitis, Kastytis. Sovietine Lietuvos, Latvijos ir Estijos nomenklatūra (19531990 m.): desningumai ir ypatumai. Daktaro disertacija (Unpubl. PhD diss.), humanitariniai mokslai, istorija (05 H) (Vytauto Didžiojo Universitetas, 2001).

Aston, T. H.; Philpin, C. H. E. (eds). The Brenner Debate: Agrarian Class Structure and Economic Development in Pre-Industrial Europe (Cambridge: Cambridge University Press, 1985).

Babinskas, Nerijus. 'Economic Challenges of the Early Modern Ages and Different Responses of European Margins: Comparative Considerations on the Basis of Historiography (The Cases of PolishLithuanian Commonwealth and Moldavian Principality)', Revista Română de Studii Baltice și Nordice / The Romanian Journal for Baltic and Nordic Studies 4, 2 (2012): 51-62. 
Babinskas, Nerijus. Moldova XIV a. viduryje - XVI a. viduryje kaip socialines struktūros tipologijos problema [Moldova in the Middle of 14th-Middle of 16th Centuries as A Problem of Typology of Social Structure]. Daktaro disertacija (Unpubl. PhD diss.), humanitariniai mokslai, istorija (05 H) (Vilniaus universitetas, 2010).

Bairašauskaitè, Tamara. 'Bajoro santykis su dvaru XIX a. pirmoje puseje: Mykolo Juozapo Römerio (1778-1853) patirtys [The Relationship of A Noble to His Estate in the First Half of the Nineteenth Century: Mykolas Juozapas Rőmeris (1778-1853)]', Lietuvos istorijos metraštis 1, 2005 (2006): 63-82.

Bairoch, Paul. 'Free Trade and European Economic Development in the 19th Century', European Economic Review 3, 3 (1972): 211-245.

Bakewell, Peter J. Silver Mining and Society in Colonial Mexico. Zacatecas 15461700 (Cambridge: Cambridge University Press, 1971).

Bauer, Arnold J. 'Rural Workers in Spanish America: Problems of Peonage and Oppression' Hispanic American Historical Review 59, 1 (1979): 34 63.

Bauer, Arnold J. 'The Hacienda El Huique in the Agrarian Structure of Nineteenth-Century Chile', Agricultural History 46, 4 (1972): 455-470.

Bauer, Arnold J. 'Chilean Rural Labor in the Nineteenth Century', American Historical Review 76, 4 (1971): 1059-1083.

Bergad, Laird W. The Comparative Histories of Slavery in Brazil, Cuba, and the United States (New York: Cambridge University Press, 2007).

Biernacki, Richard. The Fabrication of Labor: Germany and Britain 1640-1914 (Berkeley: University of California Press, 1995).

Borah, Woodrow. New Spain's Centutry of Depression (Berkeley: University of California Press, 1951).

Bowman, Shearer D. Masters and Lords: Mid-19th-Century U.S. Planters and Prussian Junkers (New York: Oxford University Press, 1993).

Boyer, Richard. 'Mexico in the Seventeenth Century: Transition of a Colonial Society', Hispanic American Historical Review 57, 3 (1977): 455-478.

Brading, David A. Miners and Merchants in Bourbon Mexico, 1763-1810 (Cambridge: Cambridge University Press, 1971). 
Brading, David A.; Cross, Harry E. 'Colonial Silver Mining: Mexico and Peru', Hispanic American Historical Review 52, 4 (1972): 545-579.

Bray, Warwick. 'The City State in Central Mexico at the Time of the Spanish Conquest', Journal of Latin American Studies 4, 2 (1972): 161-185.

Brzechczyn, Krzysztof. O wielości linii rozwojowych w procesie historycznym. Próba interpretacji ewolucji społeczeństwa meksykańskiego (Poznań: Wydawnictwo Naukowe UAM, 2004).

Brzechczyn, Krzysztof. Odrębność historyczna Europy Środkowej. Studium metodologiczne (Poznań: Humaniora, 1998).

Bumblauskas, Alfredas. Wielkie Księstwo Litewskie: wspólna historia, podzielona pamięć (Warszawa: Muzeum Historii Polski, 2013).

Bumblauskas, Alfredas. Senosios Lietuvos istorija 1009-1795 [A History of Old Lithuania 1009-1795] (Vilnius: R. Paknio leidykla, 2005).

Butkus, Zenonas. 'Valstybiniai perversmai Baltijos šalyse (1926 ir 1934 m.): panašumai ir skirtumai [Coup (d'etat) in the Baltic States (1926, 1934): Similarities and Differences]', Lietuvos istorijos studijos 18 (2006): 6981.

Chevalier, François. Land and Society in Colonial Maxico: The Great Hacienda (Berkeley: University of Colifornia Presws, 1963).

Chirot, Daniel; Hall, Thomas D. 'World-System Theory', Annual Review of Sociology 8 (1982): 81-106.

Dean, Warren. 'Latifundia and Land Policy in Nineteenth-Century Brazil', Hispanic American Historical Review 51, 4 (1971): 606-625.

Fogel, Robert W.; Engerman, Stanley L. Time on the Cross: The Economics of American Negro Slavery (Boston: Toronto, 1974).

Frank, Andre Gunder. Capitalism and Underdevelopment in Latin America: Historical Studies of Chile and Brazil (New York: Monthly Review Press, 1967).

Genovese, Eugene D. 'The Significance of the Slave Plantation for Southern Economic Development', Journal of Southern History 28, 4 (1962): 422437.

Gibson, Charles. The Aztecs under Spanisli Rulle: A History of the Indians of thle Valley of Mexico, 1519-1810 (Stanford: Stanford University Press, 1964). 
Gudavičius, Edvardas. Lietuvos istorija, t. 1: Nuo seniausiu laiku iki 1569 metu [Lithuania's History, Vol. 1: From the Oldest Times to 1569] (Vilnius: Lietuvos rašytojų sajungos leidykla, 1999).

Henfrey, Colin. 'Dependency, Modes of Production, and the Class Analysis of Latin America', Latin American Perspectives 8, 3/4 (1981): 17-54.

Hobsbawm, Eric J. 'A Case of Neo-Feudalism: La Convencion, Peru', Journal of Latin American Studies 1, 1 (1969): 31-50.

Jones, David M. 'The Importance of the "Hacienda" in 19th Century Otumba and Apan, Basin of Mexico', Historical Archaeology 15, 2 (1981): 87116.

Jučas, Mečislovas. Baudžiavos irimas Lietuvoje [Deterioratio of Serdom in Lithuania] (Vilnius: Mintis, 1972).

Jučas, Mečislovas. 'Prekyba Lietuvos kaime XVIII a.', Iš Lietuviu kultūros istorijos 4 (1964): 109-122.

Kahan, Arcadius. 'Notes on Serfdom in Western and Eastern Europe', Journal of Economic History 33, 1 (1973): 86-99.

Katz, Friedrich. 'Labor Conditions on Haciendas in Porfirian Mexico: Some Trends and Tendencies', Hispanic American Historical Review 54, 1 (1974): 1-47.

Kay, Cristóbal. 'Comparative Development of the European Manorial System and the Latin American Hacienda System', Journal of Peasant Studies 2, 1 (1974): 69-98.

Kaye, Anthony E. 'The Second Slavery: Modernity in the NineteenthCentury South and the Atlantic World', Journal of Southern History 75, 3 (2009): 627-650.

Keith, Robert G. 'Encomienda, Hacienda and Corregimiento in Spanish America: A Structural Analysis', Hispanic American Historical Review 51, 3 (1971): 431-446.

Knight, Alan. 'Land and Society in Revolutionary Mexico: The Destruction of the Great Haciendas', Mexican Studies / Estudios Mexicanos 7, 1 (1991): 73-104.

Kocka, Jürgen. 'Comparison and Beyond', History and Theory 42, 1 (2003): 3944. 
Kocka, Jürgen. 'Asymmetrical Historical Comparison: The Case of the German Sonderweg', History and Theory 38, 1 (1999): 40-50.

Kolchin, Peter. Unfree Labor: American Slavery and Russian Serfdom (Cambridge - MA: Belknap Press of Harvard University Press, 1987). Kula, Witold. An Economic Theory of the Feudal System: Towards A Model of the Polish Economy 1500-1800 / Translated from the Polish by L. Garner. Presentation by F. Braudel (London: New Left Books, 1976).

Kula, Witold. Teoria ekonomiczna ustroju feudalnego: Próba modelu (Warszava: Państwowe Wydawnictwo Naukowe, 1962).

Laclau, Ernesto. 'Feudalism and Capitalism in Latin America', New Left Review 67 (1971): 19-38.

Lago, Enrico Dal. 'Second Slavery, Second Serfdom, and Beyond: The Atlantic Plantation System and the Eastern and Souther European Landed Estate System in Comparative Perspective, 1800-60', Review (Fernand Braudel Center) 32, 4 (2009): 391-420.

Lockhart, James. 'Encomienda and Hacienda: The Evolution of the Great Estate in the Spanish Indies', Hispanic American Historical Review 49, 3 (1969): 411-429.

Makkai, Laszlo. 'Neo-Serdom: Its Origin and Nature in East Central Europe', Slavic Review. American Quarterly of Soviet and East European Studies 34, 2 (1975): 225-238.

Marx, Anthony W. Making Race and Nation: A Comparison of South Africa, the United States, and Brazil (Cambridge: Cambridge University Press, 1998).

Marx, Karl und Engels, Friedrich. Briefwechsel 4. Bd.: 1868-1883 (Berlin: Dietz Verlag, 1950).

Mathias, Peter. 'The Emergence of a World Economy 1500-1914', VSWG: Vierteljahrschrift für Sozial- und Wirtschaftsgeschichte 74, 1 (1987): 1-17.

Miller, Simon. 'Wheat Production in Europe and America: Mexican Problems in Comparative Perspective, 1770-1910', Agricultural History 68, 3 (1994): 16-34.

Miller, Simon. 'Mexican Junkers and Capitalist Haciendas, 1810-1910: The Arable Estate and the Transition to Capitalism between the 
Insurgency and the Revolution', Journal of Latin American Studies 22, 2 (1990): 229-263.

Millward, Robert. 'The Early Stages of European Industrialization: Economic Organization under Serfdom', Explorations in Economic History 21, 4 (1984): 406-428.

Mintz, Sidney W. 'The Culture History of a Puerto Rican Sugar Cane Plantation: 1876-1949', Hispanic American Historical Review 33, 2 (1953): 224-251.

Moon, David. 'Reassessing Russian Serfdom', European History Quarterly 26, 4 (1996): 483-526.

Mörner, Magnus. 'Economic Factors and Stratification in Colonial Spanish America with Special Regard to Elites', Hispanic American Historical Review 63, 2 (1983): 335-369.

Mörner, Magnus. 'The Spanish American Hacienda: A Survey of Recent Research and Debate', Hispanic American Historical Review 53, 2 (1973): 183-216.

Norkus, Zenonas. An Unproclaimed Empire: The Grand Duchy of Lithuania: from the Viewpoint of Comparative Historical Sociology of Empires / translation from Lithuanian by Albina Strunga (London and New York: Routledge, Taylor \& Francis Group, 2018).

Норкус, Зенонас. Непроголошена імперіл: Велике князівство Аитовське $з$ погляду порівняльно-історичної соціологї імперій (Київ: Критика, 2016).

Norkus, Zenonas. 'Two Hundred Years of the Theory of Historiography in Lithuania, or How Joachim Lelewel Did Become the Pioneer of Modern Comparative History', Sociologoja. Mintis ir veiksmas 1, 36 (2015): 5-31.

Norkus, Zenonas. 'Two Periods of the Peripheric Capitalist Development: Pre-Communist and Post-Communist Eastern Europe in Comparison', Polish Sociological Review 2, 19 (2015): 131-151.

Norkus, Zenonas. 'Catching Up and Falling Behind: Four Puzzles After Two Decades Of Post-Communist Transformation', Comparative Economic Research 18, 4 (2015): 63-79. 
Norkus, Zenonas. 'A Comparison of the Economic Growth of the Baltic States between the Two World Wars', World Political Science 12, 1 (2016): 1-23.

Norkus, Zenonas. Du nepriklausomybės dvidešimtmečiai: Kapitalizmas, klasės ir demokratija Pirmojoje ir Antrojoje Lietuvos Respublikoje lyginamosios istorines sociologijos požiūriu [Two Twenty-Year Periods of Independence: Capitalism, Class and Democracy in the First and Second Republics of Lithuania from the Viewpoint of Comparative Historical Sociology] (Vilnius: Aukso žuvys, 2014).

Norkus, Zenonas. On Baltic Slovenia and Adriatic Lithuania. A Qualitative Comparative Analysis of Patterns in Post-Communist Transformation (Vilnius: Apostrofa / CEU Press, 2012).

Norkus, Zenonas. 'Kapitalizmo raidos Lietuvoje bruožai ir etapai (iki 1940 m.) postmarksistiniu požiūriu [The Features and Stages of the Capitalist Development of Lithuania (before 1940) from the PostMarxist Viewpoint]', Lietuvos istorijos studijos 29 (2012): 9-36.

Norkus, Zenonas. 'Agrarinių reformų Pirmojoje ir Antrojoje Lietuvos respublikose lyginamoji istorinė sociologinė analizė [A Comparative Historical Sociological Analysis of Agrarian Reforms in the First and the Second Republic of Lithuania]', Sociologija. Mintis ir veiksmas 1, 30 (2012): 5-52.

Norkus, Zenonas. 'Imperium litewskie w międzyjednostkowych społecznościach i systemach politycznych: studium przypadku', Politeja 2 (2011): 129-154.

Norkus, Zenonas. Kokia demokratija, koks kapitalizmas? Pokomunistine transformacija Lietuvoje lyginamosios istorinès sociologijos požiūriu [Which Democracy, Which Capitalism?: Post-Communist Transformation in Lithuania from the Viewpoint of Comparative Historical Sociology] (Vilnius: Vilniaus universiteto leidykla, 2008).

Norkus, Zenonas. 'The Grand Duchy of Lithuania in the Retrospective of Comparative Historical Sociology of Empires', World Political Science Review 3, 4 (2007): 1-41. 
North, Douglass C.; Thomas, Robert Paul. 'The Rise and Fall of the Manorial System: A Theoretical Model', Journal of Economic History 31, 4 (1971): 777-803.

North, Douglass C.; Thomas, Robert Paul. 'An Economic Theory of the Growth of the Western World', Economic History Review 23, 1 (1970): 1-17.

O'Brien, Patrick. 'European Economic Development: The Contribution of the Periphery', Economic History Review 35, 1 (1982): 1-18.

Pamerneckis, Stanislovas. Agrariniu santykiu raida ir dinamika Lietuvoje: XVIII a. pabaiga - XIX a. pirmoji pusé (statistine analize) [The Evolution and Dynamics of Agrarian Relationships in Lithuania: The End of 18th Century - the First Half of 19th Century (Statistical Analysis)] (Vilnius: Vilniaus universiteto leidykla, 2004).

Pivoras, Saulius. Lietuviu ir latviu pilietinés savimonés raida: XVIII a. pabaigaXIX a. pirmoji pusé (lyginamasis aspektas) (Vilnius: Vytauto Didžiojo universiteto leidykla, 2000).

Pomeranz, Kenneth. The Great Divergence: China, Europe, and the Making of the Modern World Economy (Princeton: Princeton University Press, 2000). Przeworski, Adam. Democracy and the Market: Political and Economic Reforms in Eastern Europe and Latin America (Cambridge: Cambridge University Press, 1991).

Raila, Eligijus. Ignotus Ignotas: Vilniaus vyskupas Ignotas Jokūbas Masalskis Masalskis [Ignotus Ignotas: Vilnius Bishop Ignotas Jokūbas Masalskis] (Vilnius: Aidai, 2010).

Richards, Alan. 'The Political Economy of Gutswirtschaft: A Comparative Analysis of East Elbian Germany, Egypt, and Chile', Comparative Studies in Society and History 21, 4 (1979): 483-518.

Rodríguez, Gustavo. 'Accumulation, Capitalism, and Precapitalistic Agriculture in Bolivia (1870-1885)', Latin American Perspectives 7, 4 (1980): 50-66.

Romano, Ruggiero. 'American Feudalism', Hispanic American Historical Review 64, 1 (1984): 121-134. 
Rönnbäck, Klas. 'Consumers and Slavery: Diversified Markets for Plantation Produce and the Survival of Slavery in the Nineteenth Century', Review (Fernand Braudel Center) 31, 1 (2010): 69-88.

Sanderson, Stephen K. 'World-Systems Analysis after Thirty Years: Should it Rest in Peace?', International Journal of Comparative Sociology 46, 3 (2005): 179-213.

Schwartz, Stuart B. 'Indian Labor and New World Plantations: European Demands and Indian Responses in Northeastern Brazil', American Historical Review 83, 1 (1978): 43-79.

Silberman, Bernard S. Cages of Reason: The Rise of the Rational State in France, Japan, the United States, and Great Britain (Chicago: University of Chicago Press, 1993).

Skocpol, Theda. States and Social Revolutions: A Comparative Analysis of France, Russia, and China (Cambridge: Cambridge University Press, 1979).

Spalding, Karen. 'Hacienda-Village Relations in Andean Society to 1830', Latin American Perspectives 2, 1 (1975): 107-121.

Steenland, Kyle. 'Notes on Feudalism and Capitalism in Chile and Latin America', Latin American Perspectives 2, 1 (1975): 49-58.

Stein, Stanley J.; Stein, Barbara H. The Colonial Heritage of Latin America: Essays on Economic Dependence in Perspective (New York: Oxford University Press, 1970).

Stern, Steve J. 'Feudalism, Capitalism, and the World-System in the Perspective of Latin America and the Caribbean', American Historical Review 93, 4 (1988): 829-872.

Tomich, Dale. Through the Prism of Slavery: Labor, Capital, and World Economy (Lanham - MD: Rowman and Littlefield, 2004).

Tomich, Dale; Zeuske, Michael. 'Introduction, The Second Slavery: Mass Slavery, World-Economy, and Comparative Microhistories', Review (Fernand Braudel Center) 31, 2 (2008): 91-100.

Topolski, Jerzy. 'Continuity and Discontinuity in the Development of the Feodal System in Eastern Europe (Xth to XVIIth Centuries)', Journal of European Economic History 10, 2 (1981): 373-400. 
Topolski, Jerzy. 'The Manorial Serf-Economy in Central and Eastern Europe in the Sixteenth and Seventeenth Centuries', Agricultural History 48, 3 (1974): 341-352.

Van Young, Eric. 'Mexican Rural History since Chevalier: The Historiography of the Colonial Hacienda', Latin American Research Review 18, 3 (1983): 5-61.

Van Young, Eric. Hacienda and Market in Eighteenth-Century Mexico: The Rural Economy of the Guadalajara Region, 1675-1810 (Berkeley: University of California Press, 1981).

Van Young, Eric. 'Urban Market and Hinterland: Guadalajara and Its Region in the Eighteenth Century', Hispanic American Historical Review 59, 4 (1979): 593-635.

von Loewe, Karl. 'Commerce and Agriculture in Lithuania, 1400-1600', Economic History Review 26, 1 (1973): 23-37.

Wallerstein, Immanuel. The Modern World-System I: Capitalist Agriculture and the Origins of the European World-Economy in the Sixteenth Century (New York: Academic Press, 1974).

Wallerstein, Immanuel. The Modern World-System II: Mercantilism and the Consolidation of the European World-Economy 1600-1750 (New York: Academic Press, 1980).

Wallerstein, Immanuel. The Modern World-System III: The Second Great Expansion of the Capitalist World-Economy (New York: Academic Press, 1989).

Wallerstein, Immanuel. The Modern World-System IV: Centrist Liberalism Triumphant, 1789-1914 (Berkeley: University of California Press, 2011).

Warriner, Doreen. 'Some Controversial Issues in the History of Agrarian Europe', Slavonic and East European Review 32, 78 (1953): 168-186.

Weeks, David. 'European Antecedents of Land Tenures and Agrarian Organization of Hispanic America', Journal of Land \& Public Utility Economics 23, 1 (1947): 60-75.

Weeks, David. 'The Agrarian System of the Spanish American Colonies', Journal of Land \& Public Utility Economics 23, 2 (1947): 153-168. 
Wesseling, Henk. 'Overseas History', in: Burke, P. (ed.) New Perspectives on Historical Writing (Cambridge: Polity Press, 1992): 67-92.

Williamson, Jeffrey G. 'Globalization and the Great Divergence: Terms of Trade Booms, Volatility and the Poor Periphery, 1782-1913', European Review of Economic History 12, 3 (2008): 355-391.

Wolf, Eric R.; Mintz, Sidney W. 'Haciendas and Plantations in Middle America and the Antilles', Social and Economic Studies 6, 3 (1957): 380412.

Zientara, Benedykt. 'Z zagadanień tzw. „wtórnego poddaństwa“ w Europie Środkowej', Prezglad Historyczny 47, 1 (1956): 3-47.

Źytkowicz, Leonid. 'Kilka uwag o handlu zewnętrznym Wielkiego Księstwa Litewskiego w ostatnich latach Rzecypospolitej', Zapiski Historyczne 41, 2 (1976): 87-101.

Žiemelis, Darius. 'The Problem of the Application of the Term Second Serfdom in the History of Central Eastern Europe: The Case of Lithuanian Economy in the 16th-19th Centuries (until 1861)', Revista Română de Studii Baltice și Nordice / The Romanian Journal for Baltic and Nordic Studies 7, 1 (2015): 123-149.

Žiemelis, Darius. 'Tipologiškai artimi Lietuvai ūkiai: Čekija, Lenkija, Vengrija ankstyvaisiais Naujaisiais laikais [Economies Typologically Akin to Lithuania: the Czech Republic, Poland and Hungary in the Early Modern Period]', Lietuvos istorijos metraštis 2, 2013 (2014): 87116.

Žiemelis, Darius. 'The Socio-Economic History of Lithuania from the 16th to the 19th Century (until 1861) from the Perspective of Economic Development Concepts', Revista Română de Studii Baltice și Nordice / The Romanian Journal for Baltic and Nordic Studies 5, 2 (2013): 57-90.

Žiemelis, Darius. 'The Structure and Scope of the Foreign Trade of the Polish-Lithuanian Commonwealth in the $16^{\text {th }}$ to $18^{\text {th }}$ Centuries: The Case of the Grand Duchy of Lithuania', Lithuanian History Studies 17 (2013): 91-123.

Žiemelis, Darius. Feudalism or Peripheral Capitalism?: Socio-Economic History of the Polish-Lithuanian Commonwealth in the 16th-18th Centuries 
(Saarbrücken: Lap Lambert Academic Publishing GmbH \& Co. KG 2011).

Žiemelis, Darius. 'XVI-XVIII amžiaus Abiejų Tautų Respublikos palivarko ūkis marksistiniu bei neoinstitucionalistiniu požiūriu' [The Manor Estate Economy of the Polish-Lithuanian Commonwealth in the 16th-18th Centuries from the Marxist and Neo-Institutionalist Perspectives], Lietuvos istorijos studijos 27 (2011): 11-38.

Žiemelis, Darius. Abieju Tautu Respublikos socialine ekonominè raida XVIXVIII amžiuje: feodalizmas ar periferinis kapitalizmas? Istoriografine analize [Social Economic Development of the Republic of the Two Nations in the 16th-18th Centuries: Feudalism or Peripheral Capitalism? An Historiographic Analysis]. Daktaro disertacija (Unpubl. PhD diss.), humanitariniai mokslai, istorija (05 H) (Vilniaus universitetas, 2009).

Žiemelis, Darius. 'Lietuva Vidurio ir Rytų Europoje XVI-XVIII amžiuje: "feodalinè reakcija“ ar periferinis kapitalizmas? [Lithuania in the Central and Eastern Europe of the 16th-18th Centuries: „Feudal Reaction“ or Peripheral Capitalism?]', Lietuvos istorijos studijos 18 (2006): 51-68.

Žiemelis, Darius. 'Immanuelio Wallersteino kapitalistinès pasaulio sistemos teorija [Immanuel Wallerstein's Theory of the Capitalist WorldSystem]', Lietuvos istorijos studijos 16 (2005): 65-81.

Костющко, И. И. 'К. Маркс и Ф. Энгельс об аграрном развитии Восточной Европы', in Ежегодник по аграрной истории Восточной Европы 1970 г. (Рига, 1977): 5-13.

Меркис, Витовт Ю. 'Экспорт зерна и льна из Аитвы в 1795-1861 гг.', in: Ежегодник по аграрной истории Восточной Европь 1963 г.: (доклады и сообщения шестой сессии межреспубликанского симпозиума по аграрной истории, состоящегося в г. Вильнюсе с 19 по 24 сентября 1963 г.) (Вильнюс, 1964): 436-447. 